\title{
Pollution policies and market approaches in the Olifants River, South Africa
}

\author{
W. L. Nieuwoudt \\ University of KwaZulu-Natal, South Africa
}

\begin{abstract}
Approximately 3.4 million people live in the Olifants River Catchment in South Africa and a considerable proportion of South Africa's mining, power generation and agricultural activities are concentrated here. Environmental pollution caused by mining activity is a problem. Two pollution policies are proposed; tradable pollution permits and pollution offsets in the river. The catchment surface is fractured by mining activities, and water is drained into underground aquifers which then seep into streams. A main problem is the effluent leakage from old disused mines. Mines have been permitted to release nutrients into the streams during periods of high flow, which is called the "controlled release scheme". During the past few years, river flow was low and sufficient dilution of nutrients was not possible. Mines and power stations had to invest in desalination plants at considerable cost. It is recommended that polluters should pay a discharge tax which is not the case at present. It is further proposed that tradable pollution permits be adopted which are subject to a rule that discharges in the river are only allowed when flow is sufficiently high and that trades may only occur within certain parameters. Apart from a pollution trading program it is suggested that bio-diversity offsets be created to provide incentives for cooperation amongst stakeholders. The problem with the defunct mines is that they leak pollutants all the time including during the period when river flow is low. DWAF (Department of Water Affairs and Forestry) has accepted ownership of these mines but they may not have the technology (which is expensive) to desalinate the effluent. In an offsetting arrangement, incentives can be provided to existing mines to desalinate water from these defunct mines by allowing them to discharge a given amount in the Olifants when the water flow is sufficiently high. The above arrangement will cost the taxpayer nothing while discharge during low flow periods is reduced. A discussion was held with stakeholders of the Olifants River Forum during 2006 and support was received for some of these policy options.
\end{abstract}

Keywords: water pollution, South Africa, off-sets, tradable pollution permits. 


\section{Introduction}

In this study environmental pollution is studied in the Olifants River, South Africa with a view to suggest policy options. The Olifants River rises to the east of Johannesburg and flows north-east through the provinces of Mpulanga and Limpopo into Mozambique. Approximately 3.4 million people live in the Olifants River Catchment and a considerable proportion of South Africa's mining, power generation and agricultural activities are concentrated here (McCartney et al. [1]). The catchment also encompasses important tourist destinations (such as the Kruger National Park). It is estimated that activities within the Olifants Water Management Area generate 6\% of the GDP of South Africa.

The Loskop Dam in this Catchment is the centre of the coal mining and power generation industries (Eskom) in South Africa. These industries generate saline effluent, part of which is discharged into the river system. According to Van Stryp [2] pollution is bad while several mining operations are currently technically breaking the law due to the Department of Water Affairs and forestry's (DWAF's) lack of capacity to enforce quality standards (Lodewijks [3]). Water quality deteriorates if the level of Loskop Dam falls and with lower flow in the river the dilution capacity of the system is compromised. According to Coetzee [4] the main problem in the Loskop Dam is the effluent leak from old disused mines.

Mines act as a collector of groundwater. The catchment surface is fractured from mining, runoff decreases and water is drained into underground aquifers which then seeps into streams (Lodewijks [3]). The Klein Olifants River is an example of pollution by contaminated underground water that originates from mines. Mines pollute water due to the reaction of water with minerals. During the wet period in 1995/6 many mines filled up with water, and started spilling. Desalination plants had to be built because coalmines need to get rid of this water. The quality of the water originating from coalmines is a critical factor (Lodewijks [3]) while mines near Witbank are accused of polluting the underground water Pretorius [5].

Water quality affects agricultural crops such as tobacco and citrus negatively in the Loskop area (Pretorius [5]). This has a negative impact on export of some agricultural products that are chemically tested. Prinsloo [6] also considers algae a problem in this area as sieves are clocked.

\section{Controlled release scheme}

Presently pollution levels from mines can be brought to the required level by using the assimilative capacity of streams/rivers. A "controlled release scheme" is currently in place that controls the releases of effluent into rivers and dams. During high flow periods, when the assimilative capacity of the system is high, discharges are possible. Golder Africa Associates monitors the discharge scheme. Although this discharge system is the cheaper method, during low river flow sufficient dilution of nutrients is not possible. If the mines had not put in a 
desalination plant, they would not have been able to continue with operations as no discharge was possible during the recent period of low flow of the Olifants River (Lodewijks [3]).

This controlled release scheme is dependent on stream flow. During high stream flow the release of pollutants may not exceed required quality levels but during low flows assimilative capacity will be too low to absorb pollutants. The challenge of this approach would be the low flow periods that can be of a long duration in South Africa. For instance during the period 2001 to 2006 it was too dry to release any pollutants in the Olifants catchment (Lodewijks [3]). It is an open question whether buying water use entitlements from agriculture and/or transfers from other catchments can be used to increase the assimilative capacity of streams in dry periods. The cost and availability of sufficient water at the required time may cause such an approach non-viable.

\section{Economic theoretical considerations}

It is suggested in this contribution that economic measures may be used to complement the Controlled Release Scheme of DWAF. Two economic policies are suggested, namely transferable pollution permits and environmental offsets. Transferable pollution permits are a well known mechanism but the problem is that the above market differs from the traditional pollution markets and that rules and safeguards need to be adopted. DWAF so far had concerns with transferable pollution permits. Environmental offsets are also well known in wetland conservation but so far this is a relatively unknown tool in river management. As these techniques are suggested in the recommendations, some theoretical considerations are given.

\subsection{Transferable pollution permits}

The optimum discharge tax is conceptually indicated by the intersection of two functions. The first function shows as more is polluted the marginal cost of damage increases (marginal cost of one additional unit of pollution released). The second function shows that as more pollution is eliminated the marginal cost of elimination increases (marginal cost of one additional unit of pollution controlled). Marginal cost functions are opportunity cost functions which are by definition subjective and not observable. It is thus not possible to calculate an optimum discharge tax using econometric tools to a high degree of accuracy. The optimum discharge tax will also vary along the river as is the case with water prices in different water markets along a river, making estimation of the optimum tax impossible.

\subsection{Wetland offsets}

The concept of wetland offsets will be introduced briefly to show that this arrangement has a scientific foundation and that it could be adopted to provide incentives to stakeholders to reduce pollution in the Olifants River Catchment. 
A market for bio-diversity credits has developed in 20 states in the USA where wetlands have been constructed by some developers who then sell an offset right to others who want to drain wetlands (Randall and Taylor [7]). The authority can require the developer to make onsite offsets while in some instances it might be more beneficial to require the offset to be implemented offsite. The concept of "no net loss" in section 404 of the Clean Water Act allows individuals who wish to drain wetlands in one location to mitigate the loss by enhancing wetlands elsewhere within the same hydrological or ecological region. This trading arrangement has been proposed in South Africa for biodiversity offsets by De Wit [8] and Dickens [9]. For more information on these trading schemes the reader is referred to Randall and Taylor [7], Bjornlund [10], De Wit [8] and Dickens [9].

\subsection{Isolation paradox explains the need for institutions in off-set arrangements}

The creation of bio-diversity offsets for a river creates the incentive for cooperation amongst stakeholders which may be mines, developers, environmental groups, farmers and public land agencies. For many kinds of ecosystems (wetlands and rivers), protection of bio-diversity requires large areas (scale effect) of contiguous habitat. This is the classic isolation paradox. Supporting institutions need to be created to facilitate cooperation. Situations are often unique but it is proposed that opportunities for enhancing the environment be sought through a partnership between government and stakeholders. Due to the importance of creating institutions to promote offsets this isolation paradox is further discussed.

The isolation paradox explains that institutions are important to deal with environmental problems. Such institutions may be biodiversity offsets in wetlands and rivers. Instruments that make coordinated action in rivers beneficial may be rewarding as it may involve many independent individuals and include a vast area (scale effect).

In order to justify the creation of institutions to deal with biodiversity problems it is important to understand why institutions are needed. Economists have traditionally diagnosed environmental problems as market failures. The markets do not transmit appropriate incentives needed to achieve efficiency. Some have called for government to tax or regulate externalities. Others have argued that allocative inefficiency is caused by incomplete property rights and therefore privatization is the appropriate policy response. The latter group contend that government failure is more pervasive. The merits of these approaches will not be debated here.

The insistence on individual action or none at all can leave every one isolated and ineffective. This class of issues are called isolation paradoxes. Some economists contend that the law has evolved over time to deal with the isolation paradox problem without government interference. Examples are downstream fishermen in England formed an association and have taken upstream polluters to task while class action court cases in the USA are common in environmental pollution. For instance citizens of LA have claimed compensation from air 
polluters in a class action court case. No single citizen in LA may have enough funds to take the polluter(s) to court and even if the person has the funds he/she does not have the incentive as others will free ride on the outcome.

American law therefore created the institution of class action cases through which many victims can enlist and take offenders to court. This example also explains the scale effect that a large amount of money is involved. In biodiversity trading this scale effect is also important as large areas may be involved and the cooperation of many individuals is important. The institution of bio-diversity trading in water as discussed in this paper will provide the required cooperation to address the problem. Bio-diversity trading in water or offsets as will be discussed will provide the required cooperation to address the problem.

\section{Policy options that can be used to reduce pollution in rivers}

Markets can be used to provide incentives to stakeholders to reduce pollution. Various options are available that can be used in a complementary fashion.

\subsection{Discharge taxes}

In terms of Chapter 3 of the National Water Act (NWA) No. 36, the water needs for the effective functioning of aquatic ecosystems must be protected. Ecological sustainability refers to water (quantity and quality) required to protect the aquatic ecosystems of the water resources and ensure their sustainability. Waste is defined in terms of Section 1 (1) (xxiii) of the NWA. The calculation of charges will be based on the registered discharge waste load of salinity and phosphorus, as representing the two most widespread water quality problems in South Africa. The salt load will be estimated using electrical conductivity. Phosphorus (as the limiting nutrient for freshwater eutrophication) will be estimated using soluble phosphorus (phosphate) (DWAF [11]).

DWAF is developing a Waste Discharge Charge System aimed at incentivising polluters to reduce discharge levels. This "polluter pays principle" should become operative in 2008 (Havenga [12]). This system will distinguish between point and non-point sources. At present, discharges in the catchment are not taxed. It is recommended that polluters should pay a discharge tax which must be enforced as they use water from the river in a similar way as abstracting users of water who pay water rates.

\subsection{Tradable discharge permits}

In a permit discharge-trading market the market price of permits will be determined by the intersection of the functions discussed in section 3.1. It may not be necessary to attempt to calculate an optimum discharge tax. In a water market the market discovers the optimum price of water and participants in the market face the opportunity cost of this price. It is recommended that the same principle should be followed in discharges of pollution and that the optimum price be discovered in a pollution trading market. If polluters have to pay a discharge tax then this will reduce the market price. 
Lodewijks [13] recommended a discharge permit trading system but the following problems have been raised by DWAF and others (Lodewijk [3]). Discharges are only possible when river flow is sufficient, while the following must be considered; spatial location of mines relative to one another, and the river network which will drain the effluent into the dams. DWAF had concerns about trading monopolies and that it may affect small stakeholders negatively.

It is important that DWAF's concerns and other concerns be considered and possibly be incorporated as potential recommended rules of such a trading program. Any market has rules, for instance the Stock Exchange has opening and closing hours. A market for discharge permits will also have rules. As pollutants can only be discharged in rivers during high flow times, it is important that this rule be adopted in a permit-trading program.

Another rule in a permit-trading program may be that trade may only take place within well-defined reaches of the river. A water market has similar constraints to minimise externalities. In a water market, trade can only take place from up stream to down stream while in a pollution permit trading program, trade should go the other way as down stream trade increases the concentration of the pollutant at a down stream point.

The Olifants River Forum Stakeholder Workshop near Witbank was attended during 2006 (for list of stakeholders see Olifants River Forum [14]). Gunter [15], one of the representatives of the mines who participated, indicated that mines are definitely interested in discharge permits but thought that it may not be possible in future to obtain them from DWAF. The alternative of building desalination plants is expensive. The cost of the plant near Witbank visited is about R300 million (US\$ 42 million) (Gunter [15]). Not all this cost is fixed as the reservoir where the pollutants solidify, fill up after 15 years after which time a new site must be established and the old one is thus abandoned.

The rule that discharge is only possible during high flow is also adopted in the Hunter River Salinity Trading Program in Australia HRSTS [16]. Reason for the adoption of the Australian program is because of conflict between primary producers (livestock and irrigation farmers) and mining. Credits in the Australian program are initially allocated free to license holders based on environmental performance. Two hundred credits are auctioned every two years to replace those retired. New credits have a lifespan of 10 years and a total of 1000 credits are permitted. Auction proceeds are used to pay scheme operating cost (environmental and compliance monitoring cost). Targets are set at 900 micro siemens/cm but it may vary along reaches. Options for industry are to purchase more credits and/or to implement cleaner technologies.

\subsection{Offsets can provide incentives to mines to reduce pollution in the Olifants River from abandoned and defunct mines}

According to Coetzee [4] the pollution in the Loskop dam in the Olifants River is serious. He further is of the opinion that the main source is the leakage from abandoned old mines (pre-1956) during low flow periods. DWAF has accepted ownership of these abandoned mines. Before the promulgation of Water Act of 1956 an agreement was reached between DWAF and the Chamber of Mines that 
the liabilities with respect to water pollution of all mines that had ceased production before 1956 would lie with DWAF (Lodewijks [13]).

In an offsetting arrangement incentives can be provided to existing mines to desalinate these defunct mines and in return the existing mines could be provided a concession to discharge a given amount in the Olifants River when the water flow is sufficiently high.

The problem with the defunct mines is that they leak pollutants all the time including during the period when river flow is low. The negative environmental impact is reduced with this off-set arrangement as the pollution during low flow periods is reduced and pollutant is discharged when flow is sufficiently high. Lodewijks [3] supports such an approach. It is recommended that this approach or other offsets be further discussed between DWAF and the mines as other offset arrangements may be decided on. The mines have the technology to desalinate polluted water and have already invested hundreds of millions Rand in this. DWAF may not have the technology while a major part of the significant investment is of a fixed nature. The above arrangement will cost the taxpayer nothing and will promote a more desirable outcome.

\subsection{Offsets to mitigate negative environmental impacts of dams}

The promotion of water markets in South Africa will reduce the pressure on the construction of new dams. However, the demand for increased storable water is great in South Africa due to increased urbanization and demand from the mining sector. For instance, it is estimated that urban demand will double in the Lower Olifants River Catchment during the next decade (McCartney et al. [1]). South Africa has a fast growing urban population which is entirely different from countries such as the USA and Australia as well as Europe. Environmentalists in these countries are concerned about the environmental impact of dams. It appears that in China where urbanization is also high, dams built over-riding local opposition. It is suggested if dams are contemplated in South Africa and if impacts are negative in sensitive ecological areas that offsets be considered to mitigate negative environmental impacts. It may be possible to negotiate with the builders of a dam to eradicate alien vegetation over a stretch in the river or to make other offsets in return for waiving opposition to the construction. If offsets are, however, seen to have scientific international foundation then it is possible to strengthen their institutions and to inform stakeholders that such arrangements are possible. If stakeholders are not aware that these offsets are possible then many developments may not take place because of the opposition to such developments.

Several (potential) offsets in rivers in South Africa will be discussed. Two of the offsets are in the Olifants River Catchment (De Hoop dam and Flag Boshielo dam), while the agreement between the builders of a dam and environmentalists in KwaZulu-Natal can be seen as an offset arrangement. It appears as if these arrangements have taken place in a voluntary bargaining way between stakeholders. 
(a) De Hoop Dam located on the Steelpoort River

The building of a dam in the Steelpoort River namely the De Hoop Dam has been approved subject to a final environmental audit (Havenga [12]). The Kruger Park have been opposed to the building of the dam initially. Management in the Kruger Park now seems more supportive of the project given that the minimum river flow is such an important variable to them and that the dam may play a role in augmenting flows particularly in dry periods. Gyedu-Ababio [17] indicated that the Kruger Park might waive concerns about the building of the De Hoop Dam in the Steelpoort River if the Park gets an allocation (say 5\%) of the dam's capacity. This is not an official offer and it is not known whether it is intended as a serious statement but as a potential off-set such an arrangement should be pursued.

(b) Flag Boshielo Dam

Raising of the wall of the Flag Boshielo dam increases yield by 18 million cubic meters but eight farms were inundated as a result. As part of an off-set the canal infrastructure of Previous Disadvantage Individual (PDI) farmers downstream of the dam is being upgraded as part of the deal.

(c) Newcastle Dam

The town of Newcastle in KwaZulu-Natal is building a dam for drinking water. It has been established that 18 ha will be damaged (flooded) by construction of the dam. In exchange for flooding 18 ha of a provincial reserve, the proponent purchased more than 1000 ha of the catchment area and set aside funds to manage the remaining area to control invasive plants. The 1000 ha will be handed over to KZN wildlife for conservation (De Wit [8]).

\subsection{Privatising the eradication of alien vegetation and offsets of wetland}

Mines have bio-diversity action plans in the Olifants River Catchment, for instance a wetlands mitigation program is used whereby a previously destroyed wetland can be rehabilitated in exchange for a concession elsewhere (Lodewijks [3]). Mines intend to eradicate 2500 ha of alien vegetation that will yield 5 million cubic meters of water at a cost of R24.4 million or R4.9 per cubic meter. This appears to be the cheapest (best value) option for harvesting water (Rossouw [18]). There are other plans to obtain 13 million cubic meters of water from eradicating alien vegetation at a cost of R117 million (Rossouw [18]). These private ventures should be encouraged as they have positive social spin-offs.

\section{Conclusions}

Pollution is an example where markets fail to transmit appropriate incentives needed to achieve efficiency. There are two schools of thought, regulation through the government or a market approach. Neither approach may be effective as the insistence on individual action or none at all can leave every one isolated and ineffective. This class of issues are called isolation paradoxes. This 
coordination could be provided through biodiversity offsets which could be facilitated through the promotion of the necessary institutions.

The study is based on information collected in the Olifants River Catchment of South Africa during October 2006. The significant mining activity and power generation in the Cathment has polluted this river. Discussions were held with the main stakeholders. It is expected that polluters will be required to pay a discharge tax which is not the case at present. In addition to such a tax it is recommended that tradable pollution permits and bio-diversity offsets be adopted. Tradable pollution permits is an internationally well-known concept but it needs to be adapted for pollution in rivers as discharges should only be undertaken when river flow is sufficient to allow for dilution of chemicals. A main cause of pollution is the leakage into the river from old defunct mines during periods of low river flow. The Government has accepted ownership of the mines but they do not have the expertise or the funds to stop this pollution. It is recommended that the current mines be given an incentive in an offset arrangement. In such an arrangement the mines could be given concessions to discharge a given quantity of pollutant during high flow periods if they reduce the pollution from old defunct mines. Pollution is thus reduced during the low flow period. These offsets are also recommended to mitigate the negative environmental impacts of dams. South Africa has a vast growing urban population and the demand for potable water to supply urban needs will increase.

\section{References}

[1] McCartney, MP, DK Yawson, TF Magaglula and J Seshoka. Hydrology and Water Resource development in the Olifants River Catchment. Working Paper 76. International Water Management Institute, 2004.

[2] Van Stryp, J. Personal Communication. 10 October 2006. CEO Loskop Irrigation Board. Groblersdal. Tel 013 2623992/5.

[3] Lodewijks, H. Personal Communication. 13 October 2006. Anglo Coal and vice Chairman Olifant River Forum.

[4] Coetzee, J. Personal Communication. 26 October 2006. Mpumalanga Tourism and park Agency. Tel 0829287543.

[5] Pretorius, K. Personal Communication. 10 October 2006. Dwaf Regional Office. Groblersdal. Tel 013 2626839, Cell 0828075654

[6] Prinsloo, B K. Personal Communication. 10 October 2006. Farmer on Loskop Scheme.

[7] Randall, A and MA Taylor. Incentive based solutions to agricultural environmental problems: Recent developments in theory and practice. Journal of Agricultural Economics, 32(2) pp. 221-234, 2000.

[8] De Wit, M Provincial guideline on biodiversity offsets. Department of environmental Affairs and Development Planning. Provincial Government of the Western Cape, 2006.

[9] Dickens, C Personal Communication. August 2006. INR. University KwaZulu-Natal. Pietermaritzburg. 
[10] Bjornlund, H Market Experiences with Natural and Environmental Resources (other than water): Lessons for the Next Generation of Water Market Policies, ARC-SPIRT, 2003.

[11] DWAF. A draft paper on the development of a water resource classification system (WRCS): Draft discussion document, version 8, Pretoria, 22pp, 2006.

[12] Havenga, B. Personal Communication. 9 October 2006. Dwaf. Pretoria

[13] Lodewijks, H. The application of transferable permits for the control of saline effluent from coal mines and power stations in the Loskop Dam Catchment, MBA thesis, UNISA, 2002.

[14] Olifants River Forum, Map of Olifants River Water Management Area and key issues. Co-ordinator Marianne Nieuwoudt, Tel 0176347208 cell $0824591021,2006$.

[15] Gunter, P. Personal Communication. 26 October 2006. Olifants River Forum. Witbank.

[16] HRSTS. Hunter River Salinity Trading Scheme. http://www.environment.nsw.gov.au/licensing/hrsts/index.htm undated

[17] Gyedu-Ababio, T Personal Communication 13 October 2006. Sanparks Palaborwa.

[18] Rossouw, O Personal Communication. 10 October 2006. CEO Lebalelo Water User Association. 